\title{
Covid-19 Geleceği Nasıl Etkileyecek?
}

\author{
DOĞAN CÜCELOĞLU
}

Covid-19'u yaşamak bireyde, ailelerde, şirketlerde, toplumlarda, uluslararası ilişkilerde bir değişikliğe yol açacak mı? Bu soruyu kendime sorduğum zaman bir düşünsel yolculuğa çıkıyorum ve kendimce aşağıdaki gözlemleri yapiyorum:

Covid-19 salgını, yaşamın bir bütün olduğu gerçeğini gözler önüne serdi. Gözler önüne serdi, ama bu gerçeğin gerçekten farkına varılıp ne anlama geldiğinin anlaşılması kolay değil. Kolay değil, çünkü her olay gibi Covid-19 salgını da bireylerin, ailelerin, toplumların kendilerine özgü anlam verme sistemleri, kültürleri, inançları ve değerleri içinde anlamını bulacak. Biliyoruz, tarih boyunca olaylara farklı anlamlar verilmiş, değişik yorumlar yapılagelmiştir. Böyle olagelmiştir ve böyle olmaya devam edecektir. $\mathrm{O}$ nedenle aşağıdaki değerlendirmelerimin kendime göre yapıldığının altını çizerek devam ediyorum.

\section{Büyük resim}

Herhangi bir olayın, nesnenin, sözün kendi başına anlamı yoktur; her olay, nesne ya da fikir anlamını içinde yer aldığı çerçeveden alır. Harf anlamını içinde yer aldığı kelimeden, kelime cümleden, cümle paragraftan, paragraf kitabın bölümünden, kitabın bölümü de içinde yer aldığı kitaptan alır. Kitap da anlamını içinde yer aldığı toplumun kültürü ve içinde yaşanılan çağdan alır. Resim ne kadar büyükse, olayın anlamı o denli derin ve kapsamlı olur.

Covid-19 biyolojik bir olay olarak tanımlanıp çerçevelendiği zaman ancak o resim içinde anlam kazanır ve bu bağlam içinde aşı, ilaç, beslenme ve sosyal mesafe konuları dikkatle takip edilmeye başlanır. Ekonomik zeminde tanımlanıp çerçevelendiği zaman üretim, finans, yönetim ve dağıtım konuları yeniden değerlendirilmeye alınır. Covid-19 salgını akıl ve ruh sağlığı yönünden tanımlanıp çerçevelendiği zaman başka bir anlam kazanır ve bu anlam içinde evlilikler, iş yönetimi, eğitim mekânı ve yöntemleri üzerinde konuşulmaya başlanır. Büyük resim sadece insanların hayatını

-GÖRÜS-

DOĞAN CÜCELOĞLU, iletisim@dogancuceloglu.net doi: https://doi.org/10.47646/CMD.2020.203 
değil, doğanın tümünü içine alacak şekilde tanımlanıp çerçevelendiği zaman daha kapsamlı, daha derin bir anlam kazanır. Doğada insanın yeri ve insan yaşamının anlamı bu büyük resim içinde konuşulur.

\section{Büyüik resim ve yaşamın anlamı üstüne}

İnsanlığın, ya da bizim toplumun büyük resmi ne kadar büyük? Bu önemli bir soru. Diğer bir önemli soru da, resmin çözünürlüğü, yani büyük resmin ne kadar açık seçik ve net olduğu? Bu iki soruyu, büyük resmin kapsamı ve derinliği ile netliğini birlikte düşünmek gerekiyor.

Birey olarak kendi büyük resminin farkında olmayan biri ailesi, şirketi ya da toplumu için bir vizyon oluşturamaz. Oluşturamadığı için kendiyle, ailesi ya da şirketiyle ilgili anlamlı, açık seçik, berrak bir görüşe sahip olamaz. Olamaz, çünkü yukarıda da söylediğim gibi, olay anlamını içinde yer aldığı büyük resim içinde kazanır.

Yaşamın anlamını birey kendi içinde tanımlıyor; bilinçli ya da bilinçsiz, bulanık ya da berrak bir tanımlama, ama yaşamının anlamı bireyin kendi anlam verme sistemi içinde oluşuyor. Yaşamın anlamlı olup olmadığını sorgulayan, hisseden, farkına varan bireyin kendisi. Bana göre bireyin doğuştan getirdiği potansiyelin gelişimi, bireyin olabileceğinin en iyisi olması, insanlığın en önemli konusu. Covid-19 dönemi bu gerçeğin anlaşılıp berraklaşmasında ne kadar etkili olur? Bilemiyorum. Ama inandığımı açık seçik ifade etmek istiyorum: Bir aile, bir millet, tüm insanlık, doğan her çocuğun olabileceğinin en iyisi olmasını öncelik olarak görmedikçe yaşam anlamını tam bulamaz.

Doğan her bir çocuğun olabileceğinin en iyisi olması ve gelişmesi amacında anlaşmış, kenetlenmiş bireylerin, ailelerin, devletlerin içinde yer alacağı büyük resim aile hayatına, eğitime, ekonomik hayata, yasalara ve tüm hayata bir nizam getirecektir. Böyle bir büyük resmin getireceği nizam içinde "yaşamın anlamı ne," sorusuna birey, aile, devlet ve insanlık, aynı cevabı verebilecektir: Yaşamın amacı, doğan her bir çocuğun olabileceğinin en iyisi olarak gelişmesi için fırsatlar oluşturmaktır.

Covid-19 bu büyük resmin farkına varıp, inşa edip netleştirmemize hizmet edebilecek mi? Bu sorunun cevabını bilmiyorum, ama bu konuda konuşma ortamı oluşturacağını umuyorum.

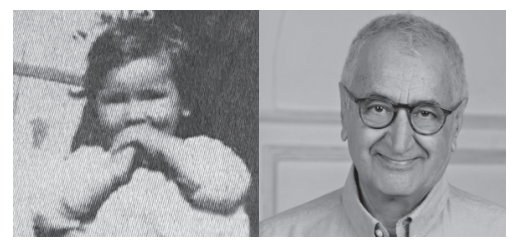




\section{Kirk Dokuz Günün Sonunda}

\section{Ahmet Kerem için}

Şenliğe gider gibi

Maskeli çıkınca evden

Önce komşu kedi Uysal'ın

Sesini duymuş dedem

Ne kadar da büyümüş

Kuşlar ağaçlar gökyüzü, diye

Şaşırmış dedem!

Yoldan aldı ̆̆

Beş salyangozu

Bırakınca çimenliğe

Unutmadiğı için

İyilik yapmayı

Sanki kanatsız

Uçmuş dedem

Dönünce eve

-Hadi, demiş, anlat

Duvardaki büyük ayna

Oturduğu bordo koltuk

-Ne gördün evde olmayan?

Gökyüzünün

Çok büyüdügüunü

Başlayınca anlatmaya

Çok sevdiği koltuğunda

Yorgun bir çocuk gibi

Uyumuş dedem!

Mustafa Ruhi Şirin 


\section{Maskeli Oyun}

Yıkayın sabunla ellerinizi!

Yıkadık!

Giydik

Eldivenlerimizi

Maske takın!

Taktık maskelerimizi

Hep yanımızda

Kuş gibi uçan

Kolonya

Uzak düşünce

"Sosyal uzaklıkla"

En sevdiklerimizden

Yalnız kaldık

Hayat eve sığar

Sözüne

Çoğumuz kandık!

Biz evdeyken

Değișince dünya

İyice şaşırdık!

Çocuğuz ama

Sanmayın bu

Bu maskeli oyuna

İnandik!

Mustafa Ruhi Şirin 